\title{
Quantal Secretion of Catecholamines Measured from Individual Bovine Adrenal Medullary Cells Permeabilized with Digitonin*
}

(Received for publication, March 6, 1992)

\author{
Jeffrey A. Jankowski $\ddagger$, Timothy J. Schroeder $\ddagger$, Ronald W. Holz $\S$, and R. Mark Wightman $\ddagger \pi$ \\ From the $\ddagger$ Department of Chemistry, University of North Carolina, Chapel Hill, North Carolina 27599-3290 and the \\ $\S$ Department of Pharmacology, University of Michigan, Ann Arbor, Michigan 48109
}

\begin{abstract}
Secretion of catecholamines from individual bovine adrenal medullary cells grown in primary culture has been investigated with a carbon-fiber microelectrode placed adjacent to the cells. Oxidation of catecholamines at the electrode surface results in changes in current, which give a real-time measure of catecholamine secretion. Chemical agents are introduced to the individual cells by pressure ejection from micropipettes. When incubated in $\mathrm{Ca}^{2+}$-containing buffers, secretion is not observed. However, permeabilization of the cell by exposure to $20 \mu \mathrm{M}$ digitonin for $\sim 15 \mathrm{~s}$ results in a $\mathrm{Ca}^{2+}$-dependent secretion, and the contents of individual vesicles are detected in the form of sharp spikes. The rate at which spikes occur is a function of the $\mathrm{Ca}^{2+}$ concentration in the external media and reaches a maximum at $19 \mu \mathrm{M} \mathrm{Ca}^{2+}$. The area of the spikes range from 0.1 to $>10$ picocoulombs, but the majority are less than 2 picocoulombs, corresponding to less than $6 \times 10^{6}$ molecules detected per spike. Histograms of the spike areas are essentially independent of the $\mathrm{Ca}^{2+}$ concentration, indicating that the population of vesicles which undergo exocytosis is the same for all concentrations. Exocytotic secretion can be distinguished from nonexocytotic release by analysis of the shape of the spikes.
\end{abstract}

The use of permeabilized cells provides a way to introduce reagents directly into biological cells while bypassing events associated with the cellular membrane. In the case of bovine adrenal medullary cells, digitonin has frequently been used to achieve permeabilization (1-5). Exposure to digitonin renders the plasma membrane permeable and is accompanied by the efflux of phenylethanolamine $N$-methyltransferase, lactate dehydrogenase, and other cytosolic soluble proteins $(1,5,6)$. Low concentrations of digitonin do not affect chromaffin granules, the catecholaminergic secreting vesicles within cells (7). Typically, studies of catecholamine secretion have involved permeabilization of all of the cells on a culture plate and introduction of the agent of interest into the media surrounding the cells. With permeabilized cells, it has been demonstrated that intracellular $\mathrm{Ca}^{2+}$ concentrations less than $1 \mu \mathrm{M}$ can induce secretion of catecholamines. The secretion appears to be exocytotic because: 1) there is proportional release into the medium of catecholamine and soluble dopa-

* This research was supported by a grant from the Office of Naval Research (to R. M. W.) and by National Institutes of Health Grant R01-27959 (to R. W. H.). The costs of publication of this article were defrayed in part by the payment of page charges. This article must therefore be hereby marked "advertisement" in accordance with 18 U.S.C. Section 1734 solely to indicate this fact.

I To whom correspondence and reprint requests should be addressed. mine- $\beta$-hydroxylase, a soluble protein marker of the granular contents (5); and 2) membrane-bound dopamine- $\beta$-hydroxylase, a marker of the chromaffin granule membrane, becomes incorporated into the plasma membrane (8).

Recently we have introduced a new procedure which is capable of the measurement of secretion of catecholamines at individual cells (9-11). The measurement is accomplished with the use of a voltammetric microelectrode placed adjacent to the cell. A potential is applied to the electrode which is sufficient to oxidize the catecholamines. During exocytotic events, the measured current appears as a series of spikes which correspond to the detection of secretion from individual vesicles $(11,12)$. When the electrode is used in the cyclic voltammetric mode, the voltammograms provide confirmation that the spikes arise from packets of catecholamines. When used in an amperometric mode (constant applied potential), the area of each spike (units of charge) gives, by Faraday's law, the number of molecules detected by the electrode. By examining the rate at which the spikes occur, a measure is obtained of the frequency of exocytotic events. Thus, for the first time, one can quantitatively measure exocytosis in real time.

In this report, we adapt the electrochemical technique that can measure the exocytosis of individual chromaffin granules to experiments with digitonin-permeabilized cells. Compelling evidence is presented that supports the conclusion that $\mathrm{Ca}^{2+}$ induces exocytosis in this preparation. We demonstrate for the first time the relationship between stable and defined $\mathrm{Ca}^{2+}$ concentrations and the frequency of exocytotic events and provide evidence that similar if not identical populations of granules are released at different $\mathrm{Ca}^{2+}$ concentrations.

\section{MATERIALS AND METHODS}

Cell Cultures-Primary cultures of bovine adrenal medullary cells were prepared from fresh tissue (9). Experiments were performed on cells which were enriched in epinephrine. To accomplish this, chromaffin cells were centrifuged in a Sorvall SS-34 fixed angle rotor with a single-step Renografin gradient $(7.5 \%, 15 \%)$ for $10-12$ min at 7700 $\times g$ and $18-22{ }^{\circ} \mathrm{C}(13)$. Two separate bands formed which represent the epinephrine- and norepinephrine-enriched fractions (14). The epinephrine-enriched band was collected and cultured as previously described (9) at a density of $6 \times 10^{5}$ cells per $35-\mathrm{mm}$-diameter tissue culture plate.

Single Cell Secretion Experiments-Experiments were performed at room temperature $\left(23.0 \pm 0.1{ }^{\circ} \mathrm{C}\right)$ between days 4 and 10 of culture The culture medium was removed from the culture plate, and the cells were placed in a sodium glutamate solution $(139 \mathrm{~mm}$ sodium glutamate, $5 \mathrm{~mm}$ potassium chloride, $20 \mathrm{mM}^{\operatorname{PIPES}^{1}}$ ( $\mathrm{pH}$ 6.6), 5.6 mM glucose, and $5 \mathrm{mM}$ EGTA $(5,15)$ ) with sufficient $\mathrm{CaCl}_{2}$ to give the desired free $\mathrm{Ca}^{2+}$ concentration. Free $\mathrm{Ca}^{2+}$ concentrations in the $\mathrm{Ca}^{2+}$-EGTA buffers were calculated with a computer program (16) with constants from Martell and Smith (17). The caiculated $\mathrm{Ca}^{2+}$

${ }^{1}$ The abbreviations used are: PIPES, 1,4-piperazinediethanesulfonic acid; EGTA, [ethylenebis(oxyethylenenitrilo)]tetraacetic acid. 
concentrations are within $20 \%$ of the $\mathrm{Ca}^{2+}$ concentrations measured with a $\mathrm{Ca}^{2+}$ electrode. The concentrations are approximately $80 \%$ greater than those used in previous publications of one of the authors (R. W. H.) which are calculated using different constants. Digitonin $(20 \mu \mathrm{M})$ applied to the cells with pressure ejection from a micropipette was prepared in a $\mathrm{Ca}^{2+}$-free solution and contained $2 \mathrm{mM}$ MgATP without glucose. For experiments in which both $\mathrm{Ca}^{2+}$ and digitonin were applied by pressure ejection, the cells were maintained in an identical buffer but containing $0.2 \mathrm{mM}$ EGTA, and the solutions for microejection contained 5 mM EGTA.

Experiments were performed on the stage of an inverted-stage microscope (Axiovert 35, Zeiss, Eastern Microscope, Raleigh, NC). Microelectrodes were positioned adjacent to a cell with a piezoelectric device (PCS-250 Patch Clamp Driver, Burleigh Instruments, Fishers, NY). The electrode was positioned by bringing it in contact with the cell such that the cell membrane was visually deformed. The electrode was then retracted $1 \mu \mathrm{m}$ to reduce the deformity in the cell but maintain the proximity of the active surface of the electrode to the cell.

Solutions were applied locally to the cells from micropipettes with a pressure ejection system (Picospritzer, General Valve Corp., Fairfield, NJ). The micropipettes were positioned $40-50 \mu \mathrm{m}$ from the cell surface with a mechanical, three-dimensional micromanipulator (Narishige Japan, Tokyo, Japan). Typical ejection pressures were 510 p.s.i. with ejection rates on the order of $1 \mathrm{nl} / \mathrm{s}$. When two micropipettes were employed, the micropipette containing digitonin was placed at a $90^{\circ}$ angle to the working electrode, while the second micropipette was placed between them at an approximate angle of $30^{\circ}$ relative to the working electrode.

Permeabilization of the cells by digitonin was confirmed with trypan blue $(0.4 \%$ solution, Sigma) which stains permeabilized cells (18).

Electrochemistry-Cylindrical carbon-fiber $(5-\mu \mathrm{m}$ radius, Thornell P-55, Amoco Corp., Greenville, SC) electrodes were prepared as described previously (19). The exposed portion of the fiber was insulated by electrochemical deposition of 2-allylphenol (10). An active surface was exposed by polishing the tip on a micropipette beveller (Model BV-10, Sutter Instrument Co., Novato, CA) at a $45^{\circ}$ angle. Electrode sensitivity was analyzed before and after the experiments with $10 \mu \mathrm{M}$ epinephrine. The reference electrode employed throughout was a saline-saturated calomel electrode.

Cyclic voltammetry and constant-potential amperometry employed a commercial potentiostat (EI-400, Ensman Instrumentation, Bloomington, IN) used in a two-electrode mode. Cyclic voltammograms (200 $\mathrm{V} \mathrm{s}^{-1}$ ) were background-subtracted. In the amperometric mode, the applied potential was $0.65 \mathrm{~V}$. The output signal was digitized and recorded on videotape with a VCR adapter (Model PCM-2, Medical Systems Corp., Greenvale, NY) at a rate of $44.1 \mathrm{kHz}$. Data were analyzed from records digitized at a rate of $2 \mathrm{~ms} /$ point and low-pass filtered (Krohn-Hite Model 3750, Avon, MA) at $100 \mathrm{~Hz}$. Signals were counted as spikes if the amplitude was 5 times greater than the root mean square noise. The spike areas, amplitudes, and width at halfheight were determined with a locally written program (11). The filtering set the lower limit of spike width at $5 \mathrm{~ms}$.

Immunocytochemistry - Chromaffin cells which had been permeabilized with digitonin-containing solution were incubated on ice for $30 \mathrm{~min}$ with $5 \%$ normal goat serum, washed twice, incubated for 30 min with rabbit anti-bovine dopamine- $\beta$-hydroxylase serum (1:200 dilution), washed twice, incubated for $30 \mathrm{~min}$ with fluorescein isothiocyanate-labeled goat anti-rabbit antibody (1:50), and subsequently washed. Cells were fixed for 30 min with $3 \%$ paraformaldehyde in 0.1 $M$ cacodylate. All solutions except the fixative contained $139 \mathrm{mM}$ potassium glutamate, $5 \mathrm{mM}$ EGTA, $20 \mathrm{mM}$ PIPES (pH 6.60), $1 \mathrm{mM}$ $\mathrm{MgCl}_{2}, 2 \mathrm{mM} \mathrm{MgATP}$, and $5 \mathrm{mg} / \mathrm{ml}$ bovine serum albumin. Cells were placed in $10 \mathrm{mg} / \mathrm{ml} p$-phenylenediamine in phosphate-buffered saline (pH 9.0)/glycerol, 1:9) and viewed with a Nikon Diaphot inverted fluorescent microscope. The anti-dopamine- $\beta$-hydroxylase antibody was a kind gift from Dr. Patrick J. Fleming (Georgetown University Medical Center, Washington, D. C.).

Reagents-The culture medium, Dulbecco's modified Eagle's medium/Ham's F-12 medium, was obtained from Gibco Laboratories. Collagenase (Type I) for digestion of glands was obtained from Worthington. Renografin-60 was purchased from Squibb Diagnostics. Digitonin was acquired from Fluka. All other chemicals were reagent grade from Sigma, and solutions were prepared with doubly distilled water.

\section{RESULTS}

Permeabilization with Digitonin-The time required to permeabilize a cell with pressure ejection of digitonin was qualitatively evaluated with trypan blue. The cell was exposed to microejections of digitonin for various times, and the cells were then exposed to trypan blue from a second micropipette. A cell was determined to be permeable if the dye was found to stain the inside of the cell. The exact time varied with the micropipette, but typically 15 to $25 \mathrm{~s}$ were required with 20 $\mu \mathrm{M}$ digitonin.

Calcium-dependent Secretion from Individual Permeabilized Cells-To examine the calcium dependence of secretion from permeabilized cells, measurements at single cells were made in culture plates containing different buffered concentrations of $\mathrm{Ca}^{2+}$. Before exposure to digitonin, spikes were not observed indicating the absence of secretion. However, when the cells were exposed to a 20 -s microejection of $20 \mu \mathrm{M}$ digitonin, secretion was observed with concentrations of $\mathrm{Ca}^{2+}$ greater than $0.6 \mu \mathrm{M}$ in the surrounding media. Secretion began a few seconds after the application of digitonin and appeared as a series of spikes on the previously flat baseline (Fig. 1). Secretion was monitored for $5 \mathrm{~min}$ following termination of the microejection of digitonin. The responses in the presence of $19 \mu \mathrm{M}$ and $48 \mu \mathrm{M} \mathrm{Ca}{ }^{2+}$ are similar with a large number of spikes with a wide range of amplitudes. At lower concentrations of buffered $\mathrm{Ca}^{2+}$, spikes are observed less frequently.

The cumulative number of spikes averaged from several individual cells is shown as a function of time in Fig. 2. Because the electrode samples secretion from only a portion of the cell surface, the measured response is a fraction of the total number of exocytotic events which occur. The cumulative number of spikes is seen to increase more slowly with lower concentrations of $\mathrm{Ca}^{2+}$, resulting in a lower cumulative number of spikes observed at the end of the 5-min measurement interval. If the cumulative number of spikes at each $\mathrm{Ca}^{2+}$ concentration is normalized to the value obtained at 5 min, the curves as a function of time superimpose. Thus, although the rate of secretion decreases with time after permeabilization, it does so in a similar manner for all $\mathrm{Ca}^{2+}$ concentrations.

The data in Fig. 2 provide a concentration response curve

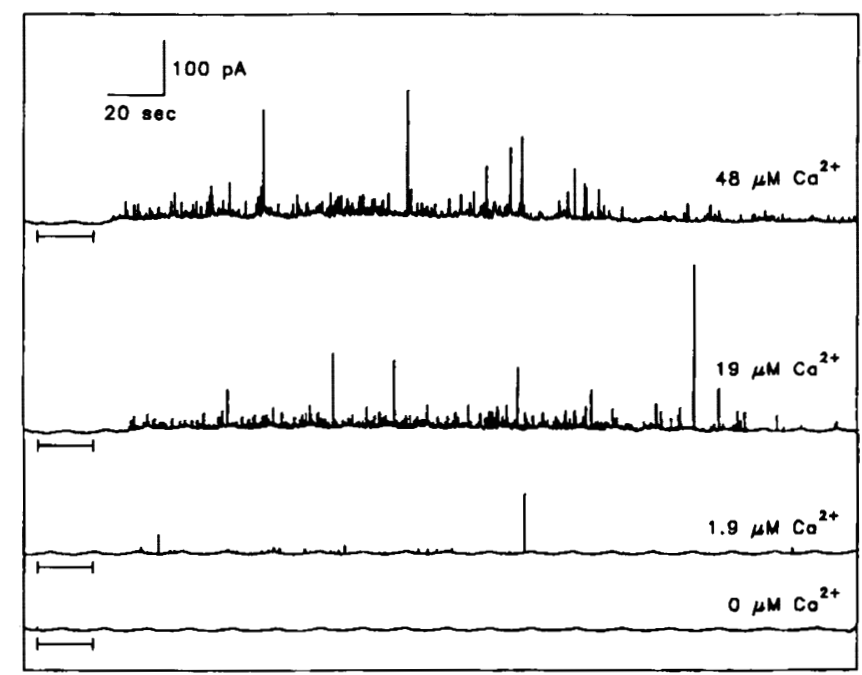

FIG. 1. Amperometric recordings of secretion from four different individual cells. Each cell was incubated in solutions buffered with concentrations of $\mathrm{Ca}^{2+}$ indicated by the concentrations on the right. The bars on the left side of each trace indicate the interval during which $20 \mu \mathrm{M}$ digitonin was introduced to the cells by pressure ejection. 


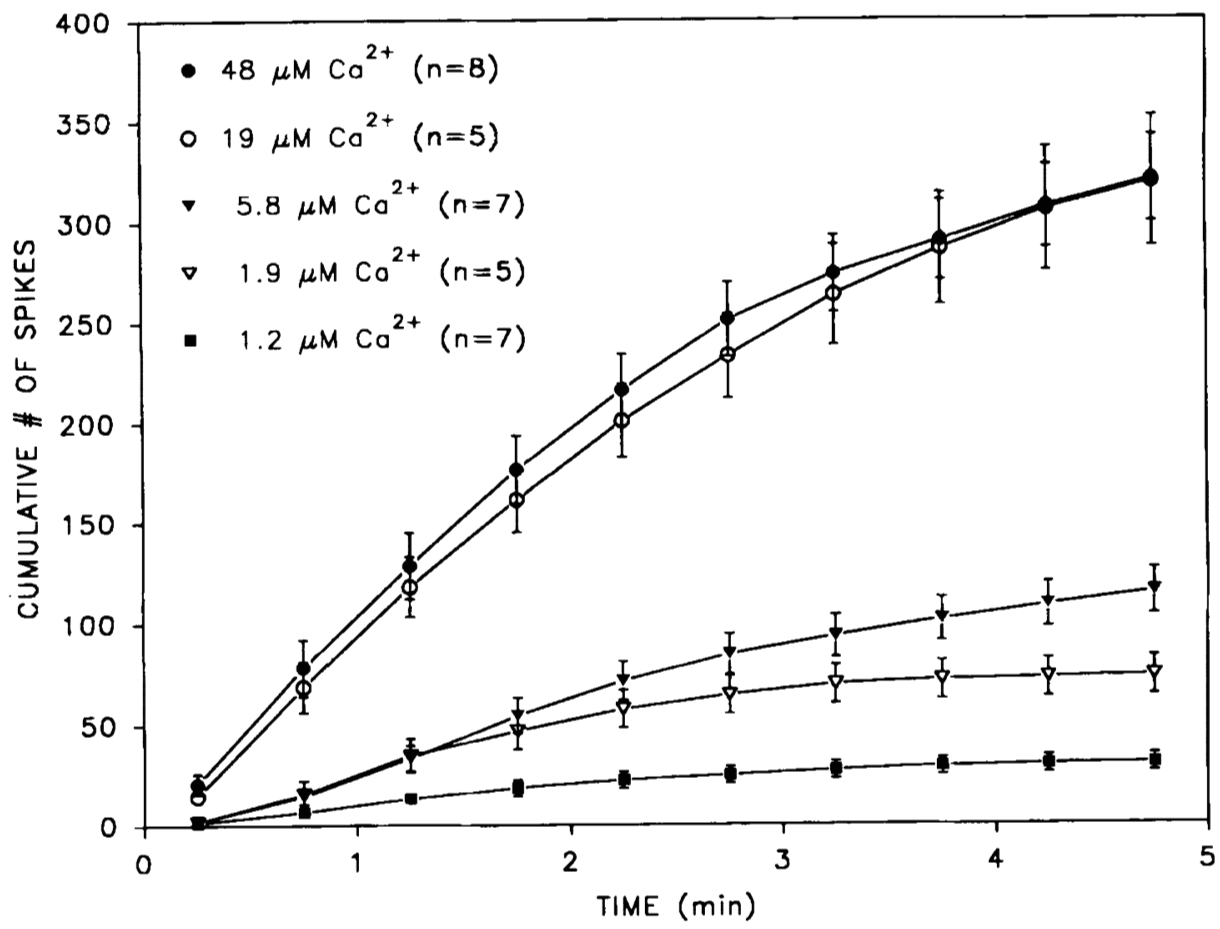

for a single time interval. The mean, cumulative number of spikes increases with $\mathrm{Ca}^{2+}$ at times greater than 3 min until $19 \mu \mathrm{M} \mathrm{Ca}^{2+}$. The values obtained at 19 and $48 \mu \mathrm{M} \mathrm{Ca}^{2+}$ are statistically the same. The cumulative number of spikes as a function of $\mathrm{Ca}^{2+}$ concentration has a form similar to that reported for catecholamine secretion measured from populations of permeabilized cells under identical conditions (2).

Characteristics of $\mathrm{Ca}^{2+}$-induced Spikes-While the frequency of spiking is a measure of the number of vesicle fusions adjacent to the electrode, the area of the individual spikes corresponds to the amount of catecholamine detected (11). Histograms of the areas of spikes obtained at permeabilized cells with each of the different $\mathrm{Ca}^{2+}$ concentrations are shown in Fig. 3. The shape of each histogram is qualitatively similar with a mean value for the spikes ranging from 1.0 to 1.8 picocoulombs. Based on Faraday's law, and assuming a twoelectron oxidation, 2 picocoulombs corresponds to $6 \times 10^{6}$ molecules $\left(1 \times 10^{-17} \mathrm{~mol}\right)$ detected.

Superimposed on each histogram in Fig. 3 is a nonlinear, least-squares fit of the probability-density function for spike areas based on the assumption of a uniform concentration of catecholamine in each vesicle and a Gaussian distribution of vesicle radii (11). For the calculated curves, a vesicle radius of $156 \pm 42 \mathrm{~nm}$ was employed, corresponding to that measured for epinephrine-containing cells (20). The vesicular concentration, the only adjustable parameter for the fit, was determined with a nonlinear regression, and the values obtained from each histogram are given in Table $I$, along with the coefficient of regression. The calculated vesicle concentrations are essentially similar, and no trend with $\mathrm{Ca}^{2+}$ concentration is seen

Response to Digitonin-To examine the effect of prolonged exposure to digitonin on bovine adrenal medullary cells, experiments were conducted in $\mathrm{Ca}^{2+}$-free media containing 0.2 mM EGTA; $\mathrm{Ca}^{2+}$ and digitonin were independently introduced to the cells through microejection pipettes. Each cell was first exposed to $\mathrm{Ca}^{2+}$, and no response was seen. Permeabilization with a 15-s application of $20 \mu \mathrm{M}$ digitonin also does not cause secretion until the cell is exposed to $\mathrm{Ca}^{2+}$ (Fig. 4, upper trace).

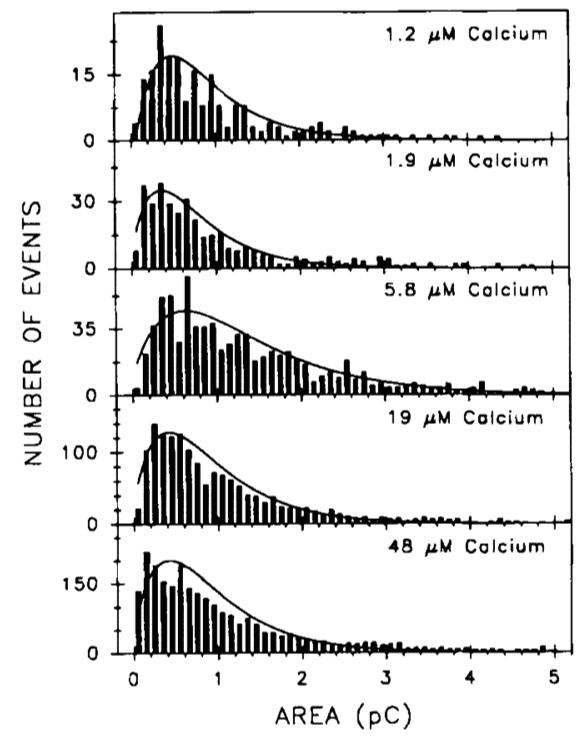

FIG. 3. Histograms of areas of spikes obtained after permeabilization with $20 \mu \mathrm{M}$ digitonin in solutions of different buffered $\mathrm{Ca}^{2+}$ concentrations. Superimposed on each histogram is a nonlinear, least-squares fit of the probability density function for the spike areas. Statistical characteristics of the histograms are given in Table I.

The $\mathrm{Ca}^{2+}$-induced spikes occur for a transient period and subside, presumably because diffusion removes the $\mathrm{Ca}^{2+}$. Subsequent microejections of $\mathrm{Ca}^{2+}$ result in similar responses.

Prolonged microejection of digitonin onto a cell causes $\mathrm{Ca}^{2+}$-independent secretion (lower traces, Fig. 4). When 20 $\mu \mathrm{M}$ digitonin was applied to a single cell (in the absence of $\mathrm{Ca}^{2+}$ ) for $30 \mathrm{~s}$, secretion is observed about $20 \mathrm{~s}$ after the onset of application of digitonin and continues for approximately 1 min. Cyclic voltammetry was used to identify the detected substances as catecholamines (Fig. 5). Subsequent exposure of this cell to $\mathrm{Ca}^{2+}$ does not induce secretion (Fig. 4, middle trace), but subsequent exposure to $20 \mu \mathrm{M}$ digitonin can restore secretion (data not shown). Application of $10 \mu \mathrm{M}$ digitonin 
for $120 \mathrm{~s}$ (one-half the concentration for 4 times longer) also results in secretion, but the frequency of spikes is lower. Thus, digitonin-induced secretion is dependent on the amount of digitonin applied by microejection in a given period of time.

Differences in Digitonin and $\mathrm{Ca}^{2+}$-induced Secretion-Secretion observed in response to digitonin is qualitatively and quantitatively different from that induced by $\mathrm{Ca}^{2+}$. Qualitatively, the spikes induced by digitonin are smaller in amplitude, wider (Fig. 6), and are superimposed on a broad background current arising from catecholamines. To quantitatively explore these differences, the response to each agent was measured at the same cell. The cell was first permeabilized with $20 \mu \mathrm{M}$ digitonin by a short exposure which itself did not result in spikes. Next, the cell was exposed twice for $5 \mathrm{~s}$ to 18 $\mu \mathrm{M} \mathrm{Ca}{ }^{2+}$ from a separate micropipette, and the spikes were recorded. Subsequently, the cell was exposed to $20 \mu \mathrm{M}$ digitonin for $60 \mathrm{~s}$. Histograms of the width at half-height of the spikes show that those induced by digitonin are much broader than those induced by $\mathrm{Ca}^{2+}$ (Fig. 6), whereas the histogram of the spike areas (data not shown) is qualitatively similar to those found with $\mathrm{Ca}^{2+}$ (Fig. 3).

TABLE I

Characteristics of spikes measured at digitonin-permeabilized bovine adrenal medullary cells during secretion induced by $\mathrm{Ca}^{2+}$

\begin{tabular}{lccccc}
\hline $\begin{array}{l}\mathrm{Ca}^{2+} \text { concentra- } \\
\text { tion }(\mu \mathrm{M})\end{array}$ & 1.2 & 1.9 & 5.8 & 19 & 48 \\
$\begin{array}{l}\text { Number of } \\
\text { spikes }\end{array}$ & 218 & 373 & 836 & 1631 & 2595 \\
$\begin{array}{c}\text { Minimum spike } \\
\left.\quad \text { area }(\mathrm{pC})^{a}\right)\end{array}$ & 0.061 & 0.054 & 0.052 & 0.055 & 0.050 \\
$\begin{array}{c}\text { Maximum spike } \\
\text { area (pC) }\end{array}$ & 9.00 & 10.2 & 15.3 & 17.8 & 31.6 \\
$\begin{array}{c}\text { Mean spike area } \\
\quad(\mathrm{pC})\end{array}$ & 1.04 & 1.07 & 1.76 & 1.30 & 1.37 \\
$\mathrm{C}^{h}(M)$ & 0.2181 & 0.2068 & 0.360 & 0.246 & 0.246 \\
$R^{\mathrm{c}}$ & 0.9032 & 0.9315 & 0.9075 & 0.9507 & 0.9130 \\
Number of cells & 8 & 5 & 7 & 5 & 7 \\
\hline
\end{tabular}

${ }^{a} \mathrm{pC}$, picocoulombs.

${ }^{b}$ Concentration of catecholamine per vesicle calculated by nonlinear regression.

' Correlation coefficient of model to data.
High concentrations of digitonin, when applied to a population of cells in a well in macroscopic experiments, causes $\mathrm{Ca}^{2+}$-independent release of catecholamine (5). This was thought to be caused by digitonin-induced lysis of intracellular granules rather than by exocytosis. Experiments were conducted to verify that exocytosis was not occurring. Chromaffin cells in a $16-\mathrm{mm}$ dish were exposed to 20 or $100 \mu \mathrm{M}$ digitonin for $6 \mathrm{~min}$ in $139 \mathrm{mM}$ potassium glutamate, $5 \mathrm{mM}$ EGTA, 2 mM MgATP, $1 \mathrm{mM} \mathrm{MgCl}_{2}$, and $20 \mathrm{mM}$ PIPES (pH 6.60). The low digitonin concentration did not cause catecholamine release, whereas the high concentration induced release of $20 \%$ of the catecholamine. Cells were then processed to detect exposed membrane-bound dopamine- $\beta$-hydroxylase immunocytochemically. Because dopamine- $\beta$-hydroxylase was not detected in the plasma membrane of cells permeabilized with 100 (or $20 \mu \mathrm{M}$ ) digitonin (data not shown), the catecholamine was probably not released by exocytosis. In contrast, when cells permeabilized with $20 \mu \mathrm{M}$ digitonin were subsequently incubated with $10 \mu \mathrm{M} \mathrm{Ca}^{2+}$, catecholamine was secreted and dopamine- $\beta$-hydroxylase appeared on the plasma membrane, a consequence of exocytosis.

Response of Permeabilized Cells to Hypoosmotic Shock-Fig. 7 shows the responses of individual cells to a 5 -s microejection of doubly distilled $\mathrm{H}_{2} \mathrm{O}$ before and after permeabilization with $20 \mu \mathrm{M}$ digitonin. Exposure to water itself does not cause secretion. However, permeabilization of the cell with $20 \mu \mathrm{M}$ digitonin followed by microejection of water leads to a large amount of secretion. This release is characterized as a broad, large envelope, with few, if any, spikes which are comprised of catecholamines as identified by cyclic voltammetry (Fig. 5 ). The release rapidly subsides when the application of water is terminated.

\section{DISCUSSION}

The primary goal of this study was to investigate catecholamine secretion from single chromaffin cells triggered by defined $\mathrm{Ca}^{2+}$ concentrations. Permeabilization of the plasma membrane by low concentrations of digitonin has permitted control of the intracellular milieu of chromaffin cells in ex-
FIG. 4. Amperometric recordings of secretion from an individual chromaffin cell in buffer containing $0.2 \mathrm{mM}$ EGTA. In the upper trace, the cell was exposed to a 15-s microejection of $20 \mu \mathrm{M}$ digitonin followed by a $10-\mathrm{s}$ microejection of $18 \mu \mathrm{M} \mathrm{Ca}{ }^{2+}$ at the times shown. The middle trace is a continuation of the upper one and shows the effect of a $30-\mathrm{s}$ application of $20 \mu \mathrm{M}$ digitonin, followed by a 30-s exposure to $18 \mu \mathrm{M} \mathrm{Ca}{ }^{2+}$. The lower trace (from a different cell) shows the response to a 120 -s microejection of $10 \mu \mathrm{M}$ digitonin.

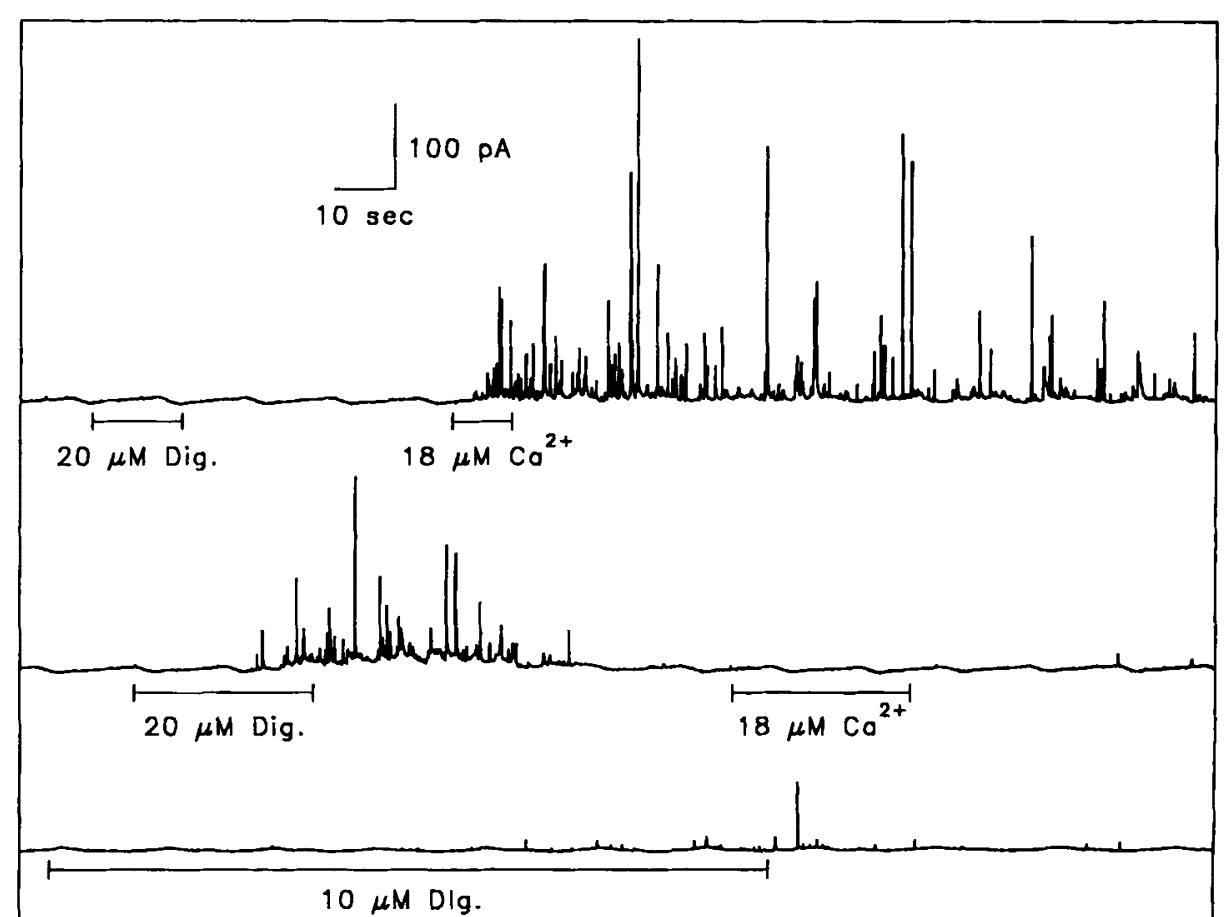


periments investigating secretion from a population of cells. The cells are permeable to salts including $\mathrm{Ca}^{2+} /$ EGTA buffers, to ATP, and to proteins $(1,5)$ and secrete catecholamine in response to micromolar concentrations of $\mathrm{Ca}^{2+}$ in the medium. Over a time course of minutes, the secretory response to $\mathrm{Ca}^{2+}$ decays. We have adapted this permeabilization technique for use with electrochemical measurements at single cells to be able to detect the release of pulses of catecholamine that correspond to the exocytosis of individual chromaffin granules.

A brief exposure $(20 \mathrm{~s})$ to $20 \mu \mathrm{M}$ digitonin was often sufficient to permeabilize individual cells to trypan blue. Permeabilization was more rapid than with whole plate incubations

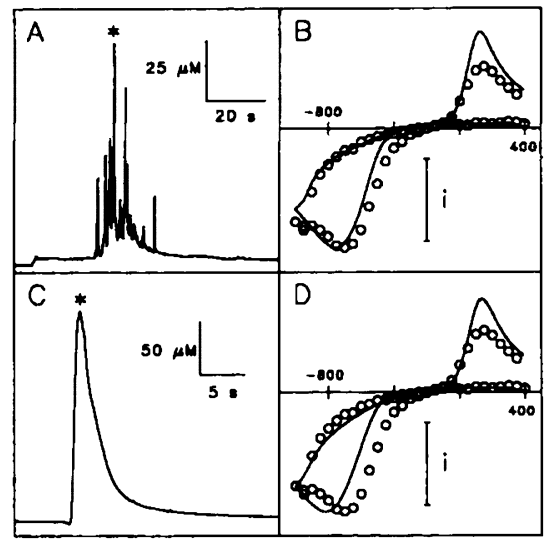

FIG. 5. Traces recorded in the voltammetric mode with a carbon-fiber electrode placed $1 \mu \mathrm{m}$ away from an individual cell. $A$, voltammetric current recorded during exposure to $20 \mu \mathrm{M}$ digitonin. Current averaged from 0.6 to $0.8 \mathrm{~V}$ on the initial oxidative scan from voltammograms repeated at 100 -ms intervals. $B$, background-subtracted cyclic voltammograms of $10 \mu \mathrm{M}$ epinephrine (circles) and substance released at the time indicated by an asterisk in panel $A$ (solid line). $i=0.25 \mathrm{nA}$ for $10 \mu \mathrm{M}$ epinephrine; $2.5 \mathrm{nA}$ for solid line. $C$, same as $A$ except recorded during exposure to $3 \mathrm{~s}$ of $\mathrm{H}_{2} \mathrm{O}$ at a digitonin-permeabilized cell. $D$, conditions as in $B$; solid line recorded at asterisk in panel $C$. $i=0.25 \mathrm{nA}$ for $10 \mu \mathrm{M}$ epinephrine; $6.0 \mathrm{nA}$ for solid line. which typically require $2 \mathrm{~min}$ with $20 \mu \mathrm{M}$ digitonin (5). The faster permeabilization in the single cell experiments is probably a consequence of the method of introduction of the digitonin-containing solution. The microejector directs the digitonin-containing solution onto the cell surface. This method of digitonin presentation increases the stirring adjacent to cells and probably increases the digitonin concentration immediately adjacent to the cells compared to cells exposed to digitonin in unstirred solutions without convection.

Micromolar $\mathrm{Ca}^{2+}$ perfused onto the cells during or after permeabilization with $10-20 \mu \mathrm{M}$ digitonin caused current pulses at the electrode with an applied oxidizing potential which corresponded to concentration spikes of catecholamines. No secretion was induced by these low $\mathrm{Ca}^{2+}$ concentrations in nonpermeabilized cells. Each spike appears to correspond to the fusion of a chromaffin granule with the plasma membrane adjacent to the electrode (11).

An important finding from this study is that the increase in catecholamine secretion induced by increasing $\mathrm{Ca}^{2+}$ concentrations in the micromolar range is the result of an increase in the rate of granule release and not due to a change in the catecholamine content of the released granules. No spontaneous spikes were observed in the absence of $\mathrm{Ca}^{2+}\left(\left[\mathrm{Ca}^{2+}\right]<\right.$ $\left.10^{-9} \mathrm{M}\right)$. The high sensitivity and resolution of the technique indicates that exocytosis under these conditions is completely $\mathrm{Ca}^{2+}$-dependent. The frequency of vesicular fusion at individual cells reaches saturation in a similar range of $\mathrm{Ca}^{2+}$ concentrations as found for release of catecholamines in populations of cells $(1,2,5)$. At the single cell level, the frequency of spike occurrence increases rapidly after initial exposure as a result of permeabilization, but decreases at longer times irrespective of the $\mathrm{Ca}^{2+}$ concentration. The independence of the time for cessation of spikes on $\mathrm{Ca}^{2+}$ concentration suggests that the cause is not a lack of vesicular availability. Rather, some other process must become rate-determining. A similar cessation of secretion has been observed with populations of cells either electropermeabilized, which are impermeant to proteins, or digitonin-permeabilized.

In addition to information concerning the frequency of
FiG. 6. Comparison of spikes obtained in response to $18 \mu \mathrm{M} \mathrm{Ca}^{2+}$ and $20 \mu \mathrm{M}$ digitonin. Upper, amperometric traces in response to $\mathrm{Ca}^{2+}$ (left panel) and digitonin (right panel). Measurements were made at the same cell with the electrode $1 \mu \mathrm{m}$ away. Lower, histograms of the half-widths of spikes obtained in response to $18 \mu \mathrm{M} \mathrm{Ca}{ }^{2+}$ (left panel) and $20 \mu \mathrm{M}$ digitonin (right panel) at the same cells ( 7 cells). Cells were first permeabilized with a short application of $20 \mu \mathrm{M}$ digitonin, twice exposed to 18 $\mu \mathrm{M} \mathrm{Ca}^{2+}$, and then given a longer exposure to digitonin.
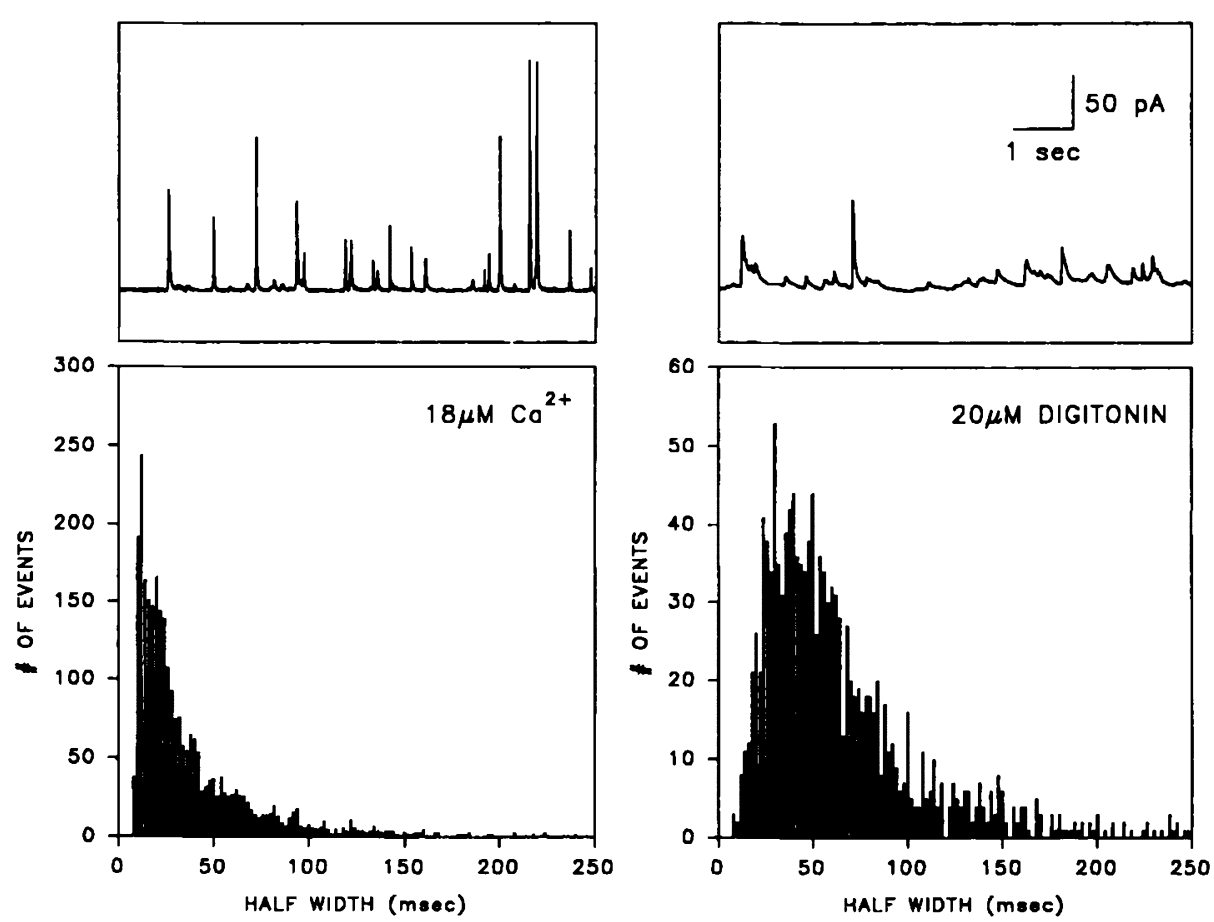


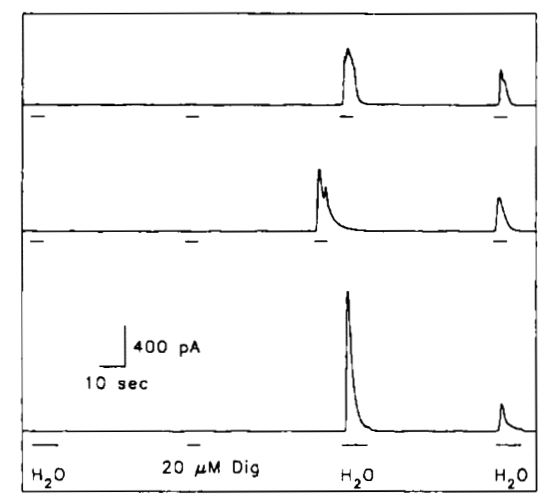

FIG. 7. Amperometric traces recorded at three individual cells during exposure to distilled water and digitonin. Water was first microejected onto the cells at the time indicated by the first bar. Subsequently, the cells were permeabilized with short applications of $20 \mu \mathrm{M}$ digitonin followed by microejection of water again. After secretion subsided, subsequent exposure of the cells to water again elicited release.

granule exocytosis and the intensity of secretion, other information can be obtained from this technique which cannot be obtained in other ways. Inspection of the individual traces during secretion shows spikes of random amplitude, which indicates many large amplitude spikes $(>75 \mathrm{pA})$. In the trace for $19 \mu \mathrm{M} \mathrm{Ca}^{2+}$ (Fig. 1), a 250-pA tall spike is obtained in the last observed minute of release. This suggests that large spikes can occur at any point during secretion in the presence of $\mathrm{Ca}^{2+}$. While only one large spike was observed in the trace shown for $1.9 \mu \mathrm{M} \mathrm{Ca}^{2+}$ (Fig. 1), the total number of spikes is low with this concentration. While such differences are striking upon initial inspection of the data, the distribution seen in the histograms shows that the events are predictable in terms of area. Each histogram of the spike areas (Fig. 3) shows a broad distribution, but the histograms are similar for all $\mathrm{Ca}^{2+}$ concentrations. Thus, the $\mathrm{Ca}^{2+}$ concentration controls the frequency of granule exocytosis but not the population of granules that undergo exocytosis.

The distribution of spike areas (catecholamine content) is fit by a probability-density function based upon a uniform catecholamine concentration in each vesicle and a Gaussian distribution of vesicle radii (11). Some of the spike areas are 4-5 times the median and fit the distribution. Although sometimes it is apparent that two or more spikes overlap, analysis of the very large spikes measured with high time resolution does not reveal structure indicative of simultaneous measurements of more than one spike. Thus, most of the large spikes probably represent exocytosis of granules with high catecholamine content. Note that this result is somewhat different from that of quantal analysis of postsynaptic responses. At a synapse, a sudden evoked stimulus induces high frequency quantal release within milliseconds. Large responses are fit by a Poisson distribution indicative of overlapping quanta.

The average calculated vesicle concentrations, determined from the fit of the probability density function to the histogram, are in reasonable agreement for each $\mathrm{Ca}^{2+}$ concentration. Note that the values obtained are in good agreement with those previously reported for a very different experiment with bovine adrenal medullary cells (11): when secretion from cells in $\mathrm{Ca}^{2+}$-containing media was induced by mechanical stimulation, a mean concentration of vesicular content of 0.19 $M$ was obtained. In all cases, the concentration may be an underestimate if not all of the secreted material is detected. However, the efficiency of detection of secreted catecholamines will depend on the spacing between the electrode and cell which was the same for all of the experiments.
Prolonged perfusion with digitonin-containing solutions in single cell experiments or incubation with high digitonin in whole dish experiments caused $\mathrm{Ca}^{2+}$-independent release. Cyclic voltammetry was used to identify the released substances as catecholamines. Although the release took the form of spikes in the single cell experiments, several features of the $\mathrm{Ca}^{2+}$-independent release suggest that it does not involve fusion of granules with the cell surface. Spikes induced by digitonin are on average smaller in amplitude than spikes induced by $\mathrm{Ca}^{2+}$ and are superimposed on a background of continuously elevated catecholamine release which is not observed with $\mathrm{Ca}^{2+}$-induced secretion. The histograms of the half-widths of the spikes show a broader distribution during exposure to excess digitonin than is found with $\mathrm{Ca}^{2+}$. The half-widths are a measure of the time course of vesicle rupture and diffusion of its contents to the electrode; an important determinant of the half-width is the distance of the electrode from the release site $(10,11)$. The majority of the $\mathrm{Ca}^{2+}$-induced spikes have half-widths of $40 \mathrm{~ms}$ or less which is the calculated value for diffusion over distances less than $5 \mu \mathrm{m}$ (9). Thus, the calcium data are consistent with secretion at the plasma membrane (i.e. exocytosis), because, although the closest approach of the electrode is $1 \mu \mathrm{m}$, the electrode is flat while the surface of the cell is curved. The greater width observed with excess digitonin must result from a different release mechanism because it was also obtained with an electrode $1 \mu \mathrm{m}$ from the plasma membrane.

Low concentrations of digitonin when applied to a dish of cells selectively permeabilizes the plasma membrane of chromaffin cells. Perfusion of single cells with a solution containing a low concentration $(20 \mu \mathrm{M})$ of digitonin caused rapid permeabilization (within $30 \mathrm{~s}$ ) of the plasma membrane without catecholamine release. Because the chromaffin granule membrane contains more cholesterol than the plasma membrane (21), prolonged perfusion with the digitonin-containing solution in single cell experiments could cause rupture of intracellular chromaffin granules. The broadening of the catecholamine spikes strongly supports this interpretation. Rapid vesicle rupture inside the permeabilized cell will result in spikes, but they will be temporally broadened because of the greater range of distances for the liberated catecholamines to diffuse to the carbon-fiber electrode. In addition, the contents of vesicles ruptured slowly or far from the electrode would contribute to the background release observed with overpermeabilization. Consistent with the conclusion that digitonininduced release is nonexocytotic is the finding that catecholamine release caused by addition of a high concentration of digitonin to a well is not associated with the appearance of dopamine- $\beta$-hydroxylase in the plasma membrane, in contrast to $\mathrm{Ca}^{2+}$-dependent secretion.

Release of catecholamines induced by exposure of permeabilized cells to water, which changes the intracellular osmolality, also appears to be nonexocytotic. Consistent with observations on populations of cells, water or hypoosmotic solutions alone do not cause secretion (22). The response of permeabilized cells to microejection of water is a steady release of catecholamine with few, if any, spikes. Low osmolality probably caused rapid swelling and lysis of chromaffin granules $(23,24)$. Their combined contents give the broad envelope of catecholamines which was observed. The effect is transient because osmolality is reattained by diffusion of the surrounding media into the cell after the microejection of water.

The results described here support the conclusions of experiments done at the level of an entire culture plate. For example, our results provide strong support for the hypothesis that secretion induced by $\mathrm{Ca}^{2+}$ from permeabilized cells is a 
consequence of the process of exocytosis. Furthermore, the close correspondence of the $\mathrm{Ca}^{2+}$ dependence of secretion measured at single cells with that determined from multiple cells provides support for previous investigations. However, the advantages of experiments done on individual cells are clear: a more detailed picture of secretion is obtained. The variability encountered with measurements at individual cells provides a measure of the difference between cells in culture. Discrete packets of catecholamine, which correspond to the exocytosis of individual chromaffin granules, can be readily measured. Fusion event frequency and vesicle contents can be determined at the single cell level with this technique. Finally, differences between exocytotic and nonexocytotic release from the bovine adrenal medullary cell can clearly be discerned by the shape of the secretion events.

Acknowledgments-Helpful discussions with E. J. Diliberto, Jr. and $\mathrm{O}$. $\mathrm{H}$. Viveros are gratefully acknowledged. We thank Mary A. Bittner for $\mathrm{Ca}^{2+}$ electrode measurements and Edward L. Ciolkowski for aid in the cyclic voltammetry experiments.

\section{REFERENCES}

1. Wilson, S. P., and Kirshner, N. (1983) J. Biol. Chem. 258, 4994-5000

2. Holz, R. W., Bittner, M. A., Peppers, S. C., Senter, R. A., and Eberhard,
D. A. (1989) J. Biol. Chem 264, 5412-5419

3. Burgoyne, R. D. (1984) Biochim. Biophys. Acta 779, 201-216

4. Burgoyne, R. D. (1991) Biochim. Biophys. Acta 1071, 174-202

5. Dunn, L. A., and Holz, R. W. (1983) J. Biol. Chem. 258, 4989-4993

6. Kelner, K. L., Morita, K., Rossen, J. S., and Pollard, H. B. (1986) Proc. Natl. Acad. Sci. U. S. A. 83, 2998-3002

7. Holz, R. W., and Senter, R. A. (1985) J. Neurochem. 45, 1548-1557

8. Schafer, T., Karli, U. O., Gratwohl, E. K.-M., Schweizer, F. E., and Burger, M. M. (1987) J. Neurochem. 49, 1697-1707

9. Leszczyszyn, D. J., Jankowski, J. A., Viveros, O. H., Diliberto, E. J., Jr., Near, J. A. and Wightman, R. M.'(1990) J. Neurochem. 56, 1855-1863

10. Kawagoe, K. T., Jankowski, J. A., and Wightman, R. M. (1990) Anal. Chem. 63, $1589-1593$

11. Wightman, R. M., Jankowski, J. A., Kennedy, R. T., Kawagoe, K. T., Schroeder, T. J., Leszczyszyn, D. J., Near, J. A., Diliberto, E. J., Jr., and Viveros, O. H. (1991) Proc. Natl. Acad. Sci. U.S. A. 88, 10754-10758

12. Chow, R. L., von Ruden, L., and Neher, E. (1992) Nature 356, 60-63

13. Moro, M. A., Lopez M. G. Gandia, L., Michelena, P., and Garcia, A. G. (1990) Anal. Biochem. 185, 243-248

14. Ciolkowski, E. L., Cooper, B. R., Jankowski, J. A., Jorgenson, J. W., and Wiowski, E. L., Cooper, B. R., Jankowski, J. A., Jorgenson, J.

15. Baker, P. F., and Knight D. E. (1978) Nature 276, 620-622

16. Chang, D., Hsieh, P. S., and Dawson, D. C. (1988) Comput. Biol. Med. 18, 351-366

17. Martell, A. E., and Smith, R. M. (1974) Critical Stability Constants, Vol. 1, Plenum Publishing Corp., New York

18. Fiskum, G. (1985) Cell Calcium 6, 25-37

19. Wightman, R. M., and Wipf, D. O. (1988) in Electroanalytical Chemistry (Bard, A. J., ed) Vol. 15, pp. 267-353, Marcel Dekker, New York

20. Coupland, R. E. (1968) Nature 217, 384-388

20. Coupland, R. E. (1968) Nature 217, 384-388

21. Wilson, S. P., and Kirshner, N. (1976) J. Neurochem. 27, 1289-1298

22. Hampton, R. Y., and Holz, R. W. (1983) J. Cell Biol. 96, 108

24. Sudhof, T. C (1982) Biochim. Biophys. Acta 74, 70-82 